\title{
Ua 'afa le Aso Stormy weather today: traditional ecological knowledge of weather and climate. The Samoa experience
}

\author{
Penehuro Fatu Lefale
}

Received: 19 November 2008 / Accepted: 31 July 2009 / Published online: 30 September 2009

(C) The Author(s) 2009. This article is published with open access at Springerlink.com

\begin{abstract}
This paper examines traditional ecological knowledge of weather and climate in Samoa, a Polynesian community in the South Pacific. The research found Samoans have their own unique seasonal calendar. The Samoan seasonal calendar is predominantly based on the observations of local environmental changes, which are in turn influenced by weather and climate. Monitoring changes in plants and animal behaviour, for example, are key indicators used by the Samoans to forecast changes in weather and climate. In addition, their communal and family social activities like hunting, fishing and feasting are driven by the seasonal calendar. The Samoans knowledge of cloud formation, conditions conducive to the formation and onset of severe weather systems and seasonal changes in climate, helped them anticipate, plan and adapt to extreme weather and climate events. The ability and knowledge of the Samoans to forecast the onset of extreme weather and climate events, relying predominantly on local environmental changes are vital tools that should be incorporated in the formulation of human induced climate change adaptation strategies.
\end{abstract}

\section{Introduction}

There is general agreement that small islands of the Pacific, their ecosystems and economies are amongst those most vulnerable to climate variability, in particular to weather and climate extremes, such as tropical cyclones, and that existing risks will be exacerbated by human induced climate change (McCarthy et al. 2001; Lefale 2006; Mimura et al. 2007). Recent climate change scenario assessments (Lefale 2006; Cristensen et al. 2007) unanimously agree with high confidence that some

P. F. Lefale $(\bowtie)$

Science, Research \& Development, MetService (Meteorological Service of New Zealand Ltd), 30 Salamanca Road, Kelburn, PO Box 722, Wellington 6140, New Zealand

e-mail: pene.lefale@metservice.com 
degree of warming is highly likely to occur in all small islands of the Pacific. This warming could alter the frequency, distribution and severity of weather and climate extremes and accelerate sea level rise in the small islands of the Pacific region, which could further increased the vulnerability of these island communities to human induced climate change. Moreover, even if concerted efforts are made to reduce greenhouse-gas emissions globally, like those articulated under the United Nations Framework Convention on Climate Change (UNFCCC) and the Kyoto Protocol, climate model projections suggest changes in climate are inevitable in all small islands due to the chaotic nature of the climate system (Lefale 2006). This makes adaptation a key component of any future climate change policy-making framework in these countries. For an adequate adaptation support system, assessments of the vulnerability and sensitivity of human and natural systems are required. Within the global climate change community, developing indicators of vulnerability or other integrated assessment techniques and tools have been the conventional approaches used to achieve this goal.

Recently, there has been growing recognition that for small islands of the Pacific, adaptation to natural climate variability, in particular, weather and climate extremes, not only promises to reduce their vulnerability in the immediate term, but also provides insights and experience that could prove valuable in enhancing their resilience to long term human induced climate change. This recognition implies that, potentially, there is considerable gain to be made from examining and documenting traditional ecological knowledge of indigenous communities on how they cope with extreme weather and climate events in the past. This is the focus of this paper. It describes the findings from a National Institute of Water and Atmospheric Research (NIWA) of New Zealand (NZ) research project that is integrating traditional ecological knowledge and practice into contemporary western scientific methodologies of climate observations, research, assessment and response to human induced climate change.

\section{Background}

\subsection{Research background}

The NIWA research into traditional ecological knowledge of weather and climate in Samoa materialised as a response to a common theme emerging from numerous climate change workshops and conferences in the Pacific and other regions over the last decade. While such gatherings acknowledge and value the role of western science in improving their understanding of climate variability and change, they place much greater emphasis on the importance of documenting traditional ecological knowledge and local observations in any response to human induced climate change (Shea et al. 2001; McCarthy et al. 2001; Barnett and Busse 2002; Jolly et al. 2002; Mimura et al. 2007; Yohe et al. 2007). This is the underlying theme underpinning this research. The goal is to document and evaluate the potential role of traditional ecological knowledge of weather and climate and how this could be integrated into contemporary western scientific methodologies of weather and climate observations, research, and assessment and response to human induced climate change. Documenting traditional ecological knowledge of weather and climate in Polynesian 
communities (Samoa and Maori) was selected for the NIWA research. This paper concentrates on the findings from the Samoan component of the research.

\subsection{Defining traditional ecological knowledge}

Much of the debate on traditional ecological knowledge at the international level is taking place in the context of intellectual property rights (IPR) through the World Intellectual Property Organization (WIPO) under the umbrella of the International Committee on Generic Resources, Traditional Knowledge and folklores (GRAIN/Kalparvriksh 2002; GRAIN 2003).

WIPO acknowledged there is no agreed definition of traditional ecological knowledge. However, they broadly defined it as it includes traditional medicinal, agricultural and ecological knowledge, as well as traditional music, stories and poems, dance, design, and sculpture." (WIPO 1999). On the other hand, Correa (2001) argued traditional ecological knowledge encompasses very different types of knowledge, which may be distinguished by the elements involved: knowledge potential or actual application, the level of codification, the individual or collective form of possession, and its legal status. She argued the different nature and forms of expression of the information embraced by traditional ecological knowledge could make it difficult to agree on a legally and scientifically acceptable definition. Berkes $(1993,2001)$ agreed. He suggested traditional ecological knowledge is defined as "[a] cumulative body of knowledge, practice, and belief, evolving by adaptive processes and handed down through generations by cultural transmission, about the relationships of living beings (including humans) with one another and with their environment" (Terralingua 2003).

In the Samoan context, a definition of traditional ecological knowledge is elusive. Meleisea (1987) contended 'for Samoans, knowledge is power, and the most powerful knowledge is historical knowledge: treasured and guarded in people's heads'. This non-written approach reflects a highly secretive nature of sharing and defining knowledge in the Samoan context. It views historical traditional ecological knowledge as 'treasures' to be guarded for a 'purpose', rather than for better and improved understanding of knowledge systems, as seen from a western perspective. Other indigenous Polynesian communities like those of the Maori of Aotearoa, N.Z, share similar experiences. Cram (1996) argued the purpose of knowledge for Maori is to 'uphold the interests and mana (power) of the group; it serves the community.' This view is endorsed by Maraketi's observation (Cram 1996).

The Maori did not think of himself, or anything to do with his own gain. He thought only of his people, and was absorbed in his whanau (group), just as the whanau was absorbed in the hapu (extended family), and the hapu in the iwi (tribe)'

Cram (1996) also contended the Maori tapu (sacred) nature of knowledge also meant that when it was entrusted to individuals it was transmitted accurately and used appropriately. Thus ethical practice was ensured as was the survival and prosperity of the group (whanau) and the maintenance of its mana (status) (Smith 1992; Te Wekotuku 1991; as cited by Cram 1996). Similar sentiments are shared by the Samoan community. 
Given the sensitive nature of what constitute traditional ecological knowledge, caution is being taken in the interpretation of the information and data gathered during this research.

\section{Research methodology}

The main sources of information and data used in this paper are those obtained from an extensive desktop review of the Samoan literature. Professor Richard Moyle, Department of Anthropology, University of Auckland, NZ provided guidance and the bulk of the literature materials on Samoa. Other main sources came from answers to participatory, unstructured, casual interviews (talanoaga faasamasama noa) carried out over 20 years (1982 to 2007) by the author.

The main informant was Mr. Taala Pauga, a high chief from the village of Laulii in Upolu. Chief Pauga is known locally as the 'Weather Guru' of Samoa. Pauga served thirty-five years as a weather observer with the Meteorological Services Division, of the former New Zealand Meteorological Service (NZMS), Apia Observatory, Samoa. He was the longest serving weather observer in Samoa. While prolific in western weather scientific techniques, Pauga is also a master in Samoan traditional weather forecasting. Another elder who assisted with the information is Mr. Taala Leapai, another long serving weather officer with the Samoa Meteorological Service. $\mathrm{He}$ is also a high chief from the village of Laulii. Other key staff of the Apia Observatory who assisted with the information includes Faatoia Malele, Steve Kamu and Ausetalia Titimaea.Leilua Akapao Akapo, chief meteorologist and chief (matai) from the US NOAA NWS American Samoa, was the other person interviewed for this research. Other key informants are listed in the acknowledgement section.

\section{Samoa}

\subsection{Geography, culture and economy}

Samoa, historically known to European traders and missionaries as the Navigator Islands and currently referred to as the Treasured Islands of the South Pacific, is an independent nation made up of a group of islands halfway between Hawaii and New Zealand between latitudes $13^{\circ}$ and $14^{\circ} \mathrm{S}$ and longitude $171^{\circ}$ and $173^{\circ} \mathrm{W}$ (Fig. 1 ). There are two large islands, Savaii $\left(1,820 \mathrm{~km}^{2}\right)$ and Upolu $\left(1,113 \mathrm{~km}^{2}\right)$ and six small islets. The population of its 214,265 people is predominantly Samoan. The main exports are agricultural, fishing and limited industrial products. The present economy is heavily dependent on tourism, fishing and remittances from the expatriate Samoan community predominantly residing in New Zealand, Australia and the USA.

\subsection{Major weather and climate features in the Samoan area}

The first major scientific assessment of the key features modulating the weather and climate of Samoa was by the former New Zealand Meteorological Service (Burgess 1988). Burgess (1988) found the main factors affecting the weather and climate of Samoa are the sub-tropical high pressure zone, which is a belt of high pressure 


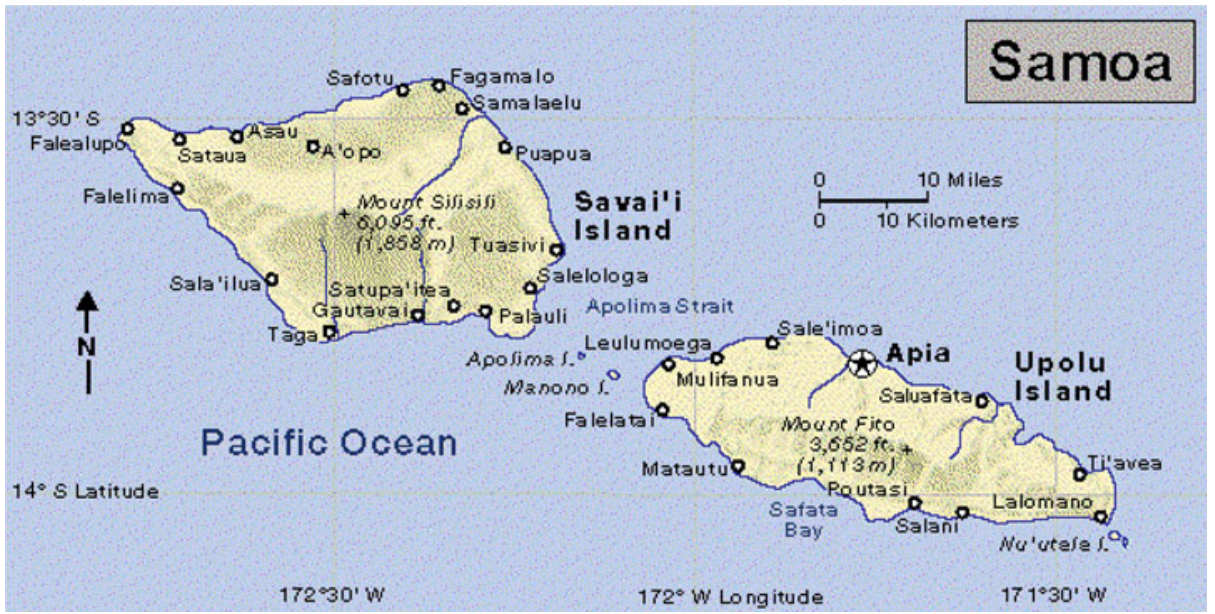

Fig. 1 Map of Samoa

spanning the South Pacific and centred on latitudes $25^{\circ}$ to $30^{\circ} \mathrm{S}$, the trade winds, the South Pacific Convergence Zone (SPZC) and the effect of the El Niño Southern Oscillation (ENSO) on the SPCZ (Fig. 2).

The SPCZ is one of the most significant features of sub-tropical Southern Hemisphere climate (Trenberth 1976; Folland et al. 2002; Mimura et al. 2007). It is

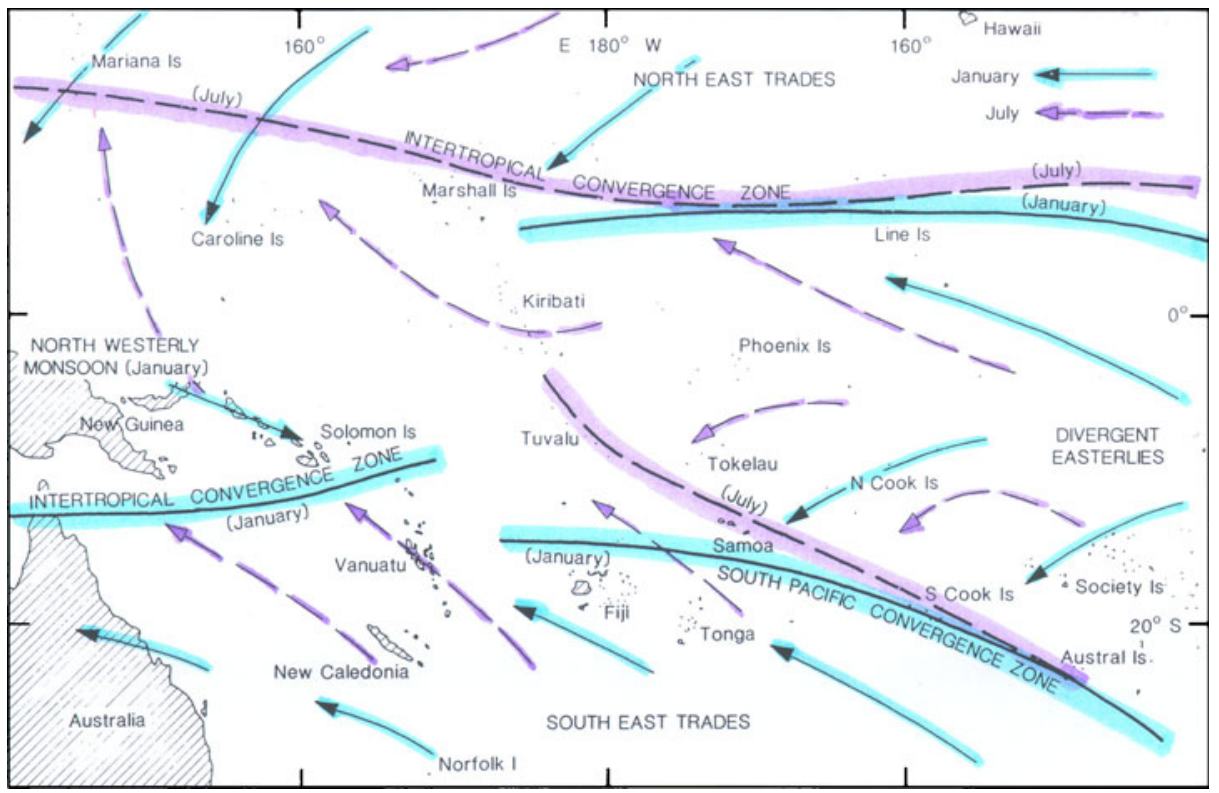

Fig. 2 Typical Southern hemisphere summer (January, solid) and winter (July, dashed circulation of the Southwest Pacific) 
characterised by a band of low-level convergence, cloudiness and precipitation lying from the west Pacific warm pool south-eastwards towards French Polynesia (Fig. 2). It shares some characteristics with the Inter Tropical Convergence Zone (ITCZ), which lies just north of the Equator, but it is more extra tropical in nature, especially east of the Date Line. The SPCZ is also one of the most extensive features of the global atmospheric circulation. Its location varies systematically with ENSO-related expansion and contraction of the west Pacific warm pool (Trenberth 1976). Such movements can result in very large precipitation anomalies on either side of the mean location of the SPCZ (Salinger and Jones 1996; Salinger 2001a, b; Manton et al. 2001; Lefale 2006; Mimura et al. 2007), as it moves northeast during El Niño events and south-west during La Niña events.

The SPCZ lies over the Samoan group during most of the year, but is especially active during the wetter months (October to April). The SPCZ therefore plays a major role in influencing Samoa's microclimate and its location and movement at any given time are crucial in understanding local weather and climate conditions.

Beucher (1997) demonstrated that the location and movement of the SPCZ are directly linked to the relationship between the trough, pressure anomalies and the SPCZ. The location of the SPCZ may be defined in terms of extremes of cloudiness (Outgoing Long wave Radiation (OLR)), low-level convergence, or related behavior of other climate features such as the trade winds shown in Fig. 2 (Folland et al. 2002). Using the trough, pressure anomalies and the SPCZ relationship, Beucher quantified an index, the SPCZ Position Index (SPI), which is now used both to determine the position and to follow the movement of the SPCZ during the warm season (October to April). The SPI is calculated using the monthly difference of pressure anomalies between Apia, Samoa and Laucala Bay, Suva, Fiji. Beucher's analysis of the SPI was also extended to different phases of ENSO. Beucher found that in normal events, when the SPI is near zero, the SPCZ lies northwest and southeast along the trough where maximum rainfall anomalies are observed. During El Niño events, when the SPI is lower than -0.47 , the SPCZ moves east of the $180^{\circ} \mathrm{W}$ meridian and lies along the most negative pressure anomalies, while during the highest positive rainfall, anomalies are observed. During La Niña events when the SPI is higher than 0.64, the SPCZ moves westwards and lies along the most negative pressure anomalies, while the highest positive rainfall anomalies are observed. Samoa becomes wetter in normal years, drier in El Niño years and records average conditions in La Niña years.

The Southern Oscillation Index (SOI) also has a major influence on the climate and weather of Samoa. When the averaged SOI for the year is positive, the SPCZ is located further to the south of Samoa than usual (Burgess 1988). This means that the frequency of winds from between north and northeast is likely to be greater than usual. Saifaleupolu (1985), noted that winds from west through north to east were more frequent than usual at $1.5 \mathrm{~km}$ above mean sea level, and that winds from east through south to west were more frequent than usual at $12 \mathrm{~km}$, when the SOI was positive. There was a complete reversal, with winds from east through south to west being more frequent than usual at $1.5 \mathrm{~km}$, with a negative SOI. Analysis of surface wind direction at Apia and Faleolo for the period 1969 to 1983 showed that the annual frequency of winds between north-east and south-east and the SOI had correlations of 0.66 and 0.64 respectively, being significant at the 99 percent level (Burgess 1988). This means that winds are more frequent from these directions when the mean annual value of the SOI is higher than usual. Seasonal wind variation 
differences are governed mainly by the position of the SPCZ relative to Samoa. During the wetter part of the year, the SPCZ is located to the south of Samoa, and the mean wind flow at the surface is easterly. Winds from west to north-west have a low frequency throughout the year, but occur more often in these months than during the drier part of the year. During the dry season winds on Savai'i and Upolu blow from between east and southeast, south-easterlies being more frequent on the southern coasts because of the greater exposure there.

Recent studies (Salinger et al. 2001; Hastenrath 2002; Folland et al. 2002; Mimura et al. 2007) also show other factors, like the Interdecadal Pacific Oscillation (IPO) and human induced climate change, could influence the weather and climate of Samoa. The extent of the local effects of human induced climate change on Samoa is not yet known.

\section{Samoan traditional ecological knowledge of weather and climate}

Samoans view the environment as a total, integrated system with many weather and climate phenomena being directly caused by activities of ancestral beings (Brown et al. 1974; Turner 1884; Overton 1999). Similar views are shared among other indigenous communities (Davis 1997). Samoans have an extensive knowledge of cosmology, which they use extensively to predict environmental changes, including changes in climate and weather (Brown et al. 1974). Myths and legends reflect such knowledge.

\subsection{Reading the sky}

The ocean-atmosphere interaction is the key modulator driving changes in weather and climate of oceanic small islands. Like many indigenous societies, Samoans are keen observers of nature, including changes in weather and climate (Kerr 1976). Some of the first European explorers named the Samoa islands the Navigator Islands, for they were impressed with their sea-faring and navigational skills, using the stars and the ocean currents to guide their voyages. Not surprisingly, Samoans had their own names for stars and the universe.

Fetu was the word designated to all heavenly bodies except the sun and the moon. Tapuitea, the morning and evening star, is the name for Venus. Matamemea, the star with the sea-leafed face is Mars. Mataalii, is the Pleiades while amoga, the Belt of Orion is a burden carried on a pole across the shoulders. Aniva, the Milky Way is often referred to in love songs. Fetu afi, "stars going to fetch a light" is the term for meteorites. Pusa loa, "elongated smoke" are comets.

$L a$, the sun, was used as the timekeeper of the day. The night was divided into three distinct periods, tulua o po ma ao, the divide between night and day or midnight, vivini mиатиа ma le vivini mulimuli a moa, the first and second cockcrowing, and the oso ae le la, the rising of the sun. The sun's movement is further categorized into six time zones-tu fa'atafa le la, the sun is quarter way up $\left(90^{\circ}\right.$ from the horizon), tu sa'o le la (standing perpendicular), the sun's slightly to the west, $t u$ sipa le la $\left(135^{\circ}\right)$, the sun in its final turning position, aga'i ina goto le la, the sun is starting to set, and finally, goto le la, or the sun-set. 
A Samoan legend tells of the blazing sun going down into the ocean, passing through it and emerging next morning on the other side of the ocean (Brown et al. 1974; Turner 1884). Samoans are highly superstitious and one of the worst curses to wish someone was that they would sink into the ocean and the sun would go blazing down on top of them. This may explain the reference to the ocean area beyond the village of Falealupo in Savaii, the most western spot on the Samoan group, as fafa $o$ sauali' $i$, or the house of ghosts. A more logical explanation is Samoans' beliefs that the fafa o saual'ii is the point of departure of human souls after death.

Other Samoan myths speak of a heaven that ends at the horizon. Samoans contend distant voyages closer to Falealupo, is considered a visit to the end of heaven. According to Samoan folklores, when the early European explorers, traders and missionaries first arrived Samoans thought that they and their vessels had in some way broken through the heavens, and to this day people with pale skins (Europeans) are referred to as Papalagi, the Heaven-busters. A recent theory about the origin of the term papalagi states that the term is the Dutch word for 'cloth', which was an important early trade item (Moyle R, personal communication, 2003).

The masina, moon, is the timekeeper of the year. The phases of the moon, vaega o le masina, are also well described by the Samoans. Masina fa'atoa is the new moon. The full moon is known as ua atoatoa le masina. The last quarter moon is referred to as ua matofitofi le masina (Pratt 1862).

\subsection{Reading the clouds}

Clouds (ao) are named according to their shapes and movement. Table 1 provides a comparison of cloud types. Cloudy conditions during the day are referred to as ao lagiā or ao lagilagiā, while cloudy conditions at night are referred to as fa'atinifü (Pratt 1862).

Ao, means-daylight, cloud, above or head-each representing something to do with day, cloud, head-overhead. It is highly likely the naming of clouds by the Samoans is related to some heavenly body-flying overhead during the day.

Lele means "flying" so the highest clouds are called flying clouds. Po' $a$ means "layered" so aо po'a are layered clouds. Fa'auliuli means something appearing dark, black or evil so ao faauliuli refers to those threatening clouds. Fulifao means

Table 1 Samoan names and descriptions of the various types of clouds and their western scientific equivalents

\begin{tabular}{|c|c|c|c|}
\hline Scientific & Samoan & Group of clouds & $\begin{array}{l}\text { Forecast weather and } \\
\text { climate conditions }\end{array}$ \\
\hline Cirrus & Ao lele & Streak cloud & $\begin{array}{l}\text { Indicates warmer weather } \\
\text { coming }\end{array}$ \\
\hline Cirrostratus & $?$ & Layer of streak cloud & \\
\hline Cirrocumulus & ? & Billowy streak cloud & Indicates rain is likely later \\
\hline Altocumulus & ? & Medium level cloud & \\
\hline Stratus & Ao po’a & Layered cloud & Indicates rain tomorrow \\
\hline Cumulus & Ao fa'auliuli & Heap, dark cloud & Indicates heavy rain soon \\
\hline Stratocumulus & Ao fulifao & Cross between layer and heap & Indicates a warm sunny day \\
\hline Nimbostratus & Ao to'a & Mainly layer cloud & Probably drizzle \\
\hline Cumulonimbus & Ao valevale & $\begin{array}{l}\text { Mainly heaped cloud. Inauspicious, } \\
\text { threatening cloud. }\end{array}$ & Thunder and lightning \\
\hline
\end{tabular}


turning upside down so thus the name given to Stratocumulus. To'a means calm or non-threatening so Ao To'a refers to those non-threatening clouds. Valevale means threatening so Ao valevale refers to those scary and highly threatening clouds.

The naming of clouds by Samoans is based on physical characteristics, heights, and shapes of the clouds. Samoans classification of clouds is consistent with western classification.

\subsection{Types of wind}

Samoan people categorised the wind types-matagi-and tropical cyclones-afaaccording to the wind direction and intensity. There are high winds, confused winds, quiet winds, boisterous winds, and land beating winds (Turner 1884). Table 2 provides the Samoan names of the key winds affecting the island.

Cyclopedia of Samoa (1907) description of Samoans reference to tropical cyclones is worth noting:

The natives [Samoans] have a word-afa-to describe the peculiar circle which a cyclone makes. The winds begin to blow from one point of the compass, usually the north, and gradually growing in intensity shifts from point to point until the circuit of the compass has been made. Then it is that, having regained the starting point, the destruction begins... [h] ence when the natives cry $O$ le $A f a$ arises ("it will be the four"- the wind that is, will blow from all points of the compass), it is a signal; for immediate preparation to ensure the safety of houses and other property. In a few minutes the work of a lifetime may be utterly destroyed.

A Samoan proverb Ua 'afa le aso-Stormy (hurricane force) weather conditions today - is common knowledge amongst the Samoans.

To interpret wind types, the literal meaning of the Samoan words was used to deconstruct compound terms and so attempt to determine their origins. Matu means

Table 2 Names and descriptions of wind types

\begin{tabular}{|c|c|c|c|}
\hline Scientific & Samoan & Direction & Forecast weather and climate conditions \\
\hline North & Matu & $\mathrm{N}$ & $\begin{array}{l}\text { This wind is a nuisance, it will } \\
\text { cause many tempests }\end{array}$ \\
\hline South & Tuaoloa & S & $\begin{array}{l}\text { Bad winds. In American Samoa, folklore } \\
\text { described Tuaoloa as the wind that } \\
\text { will stop blowing when the quotas } \\
\text { of deaths are met. }\end{array}$ \\
\hline Easterly & Mata Upolu & $\mathrm{E}$ & $\begin{array}{l}\text { Indicates bad weather, accompanied } \\
\text { by heavy rain }\end{array}$ \\
\hline Westerly & La'i & $\mathrm{W}$ & Cool climate associated with clear skies \\
\hline South Easterly & Tua Upolu & SE & Good weather \\
\hline$?$ & Laufala & $?$ & $?$ \\
\hline$?$ & Faati'u & $?$ & $?$ \\
\hline$?$ & Piipapa & $?$ & $?$ \\
\hline South-South-West & Tonga & SSW & Bring rain and inducing drowsiness \\
\hline Gentle breeze & Fisaga & NE trade winds & $\begin{array}{l}\text { Gentle, pleasant wind associated } \\
\text { with good weather. }\end{array}$ \\
\hline
\end{tabular}




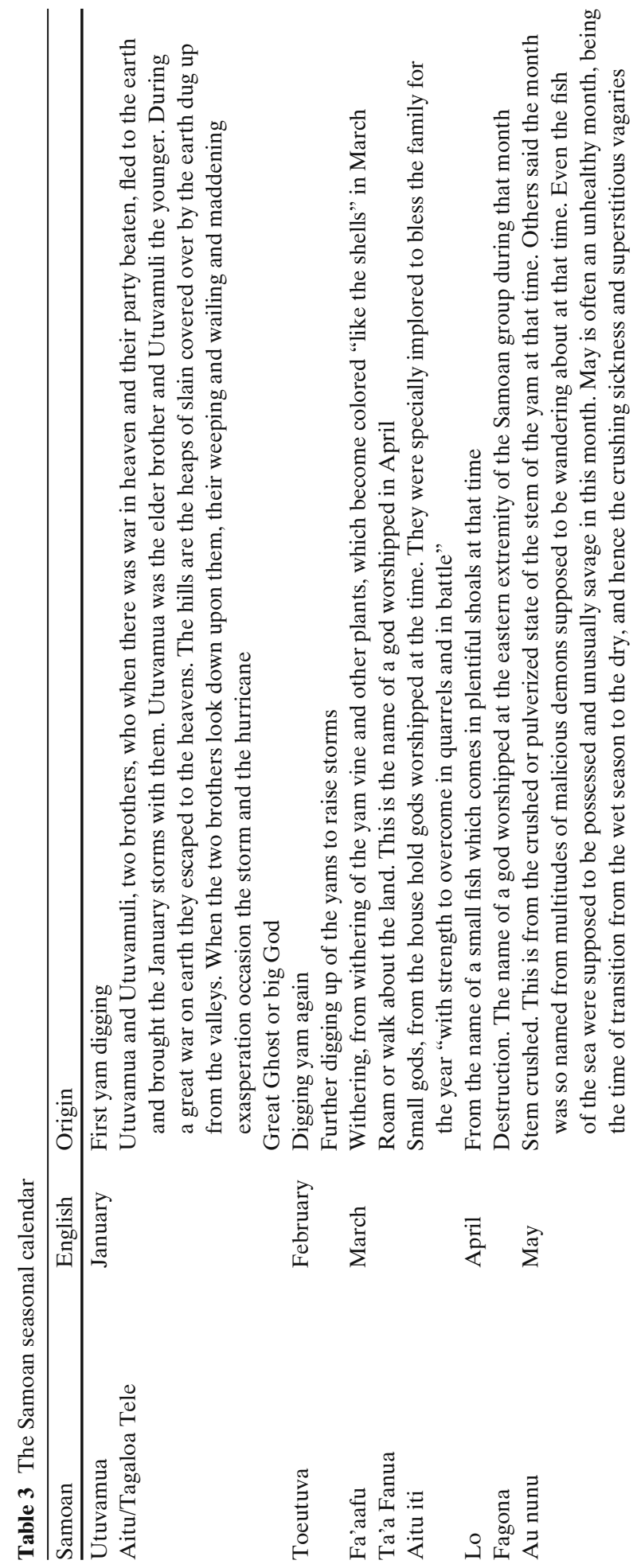




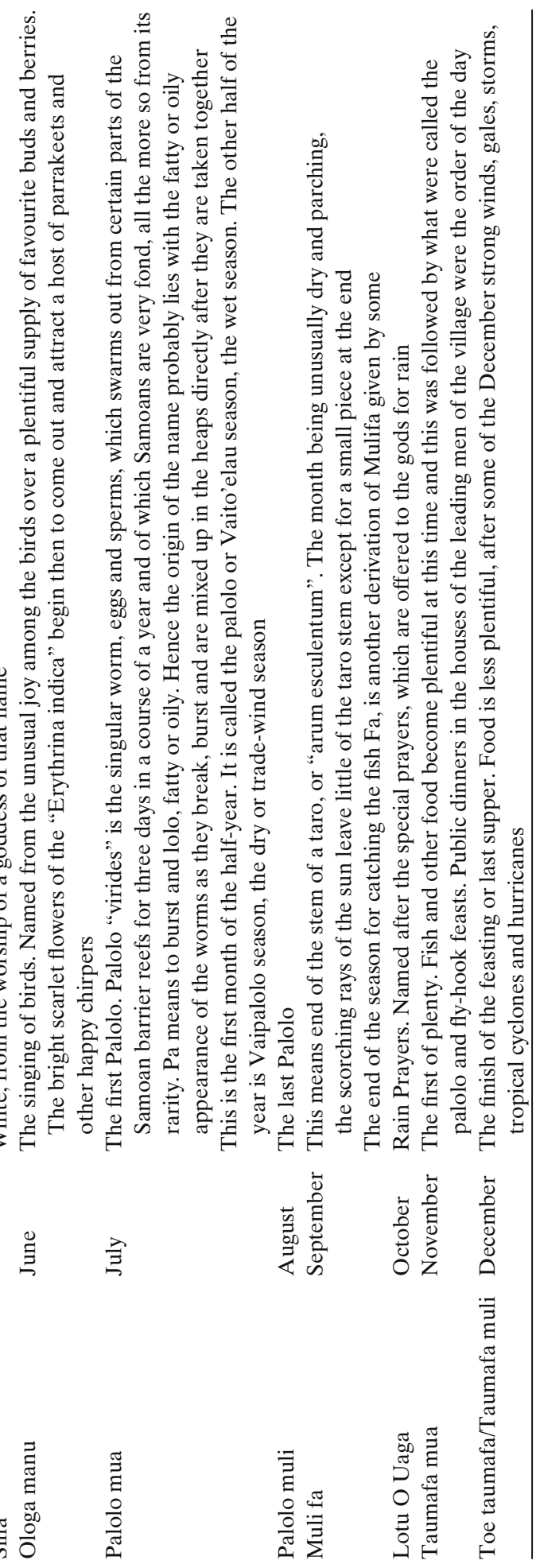


dry so the northerly winds (matagai mai in Matu) are dry winds. Tua means back and oloa means to destroy so Tuaoloa means back winds that could cause destruction. Mata means eye so Mata Upolu are winds from the eye of Upolu. To'elau is the name of the Polynesian island groups to the north of Samoa so the trade winds blowing from the To'elau direction are named matagi To'elau. Tua means back, windward or ocean coast so the winds blowing from the back or windward side of Upolu islandwhich are the predominantly southeasterly trade winds.

Matagi Tonga is the name given to winds from Tonga, which is to the south west of Samoa. Fisaga means gentle so name the gentle breeze that dominate during the dry months (May-September). La'i means sun setting so the name given to the westerly winds, where the sun sets.

It is highly likely that the naming of winds by the Samoans relies on their knowledge of their local surroundings using their islands as the centre of their universe. The naming of the winds by the Samoans is consistent with western scientific classification of winds affecting the Samoa islands group as described in Section 4.2 above.

\subsection{Samoan seasonal calendar}

The research revealed Samoans have their own seasonal calendar, described in Tables 3 and 4. Unlike the European calendar, which is predominantly based on astronomical events, the Samoan calendar is based on the onset of extreme weather and climate events and other environmental indicators, particularly the palolo, edible sea worm, virides. Some months have more than one name, depending on the village concerned, island and people's affiliation.

Table 4 The Samoan seasonal calendar and its origin (Adapted from Turner (1861) with additional inputs by Lefale)

\begin{tabular}{|c|c|c|c|c|}
\hline $\begin{array}{l}\text { European } \\
\text { month }\end{array}$ & $\begin{array}{l}\text { Samoan } \\
\text { month }\end{array}$ & Origins & $\begin{array}{l}\text { European } \\
\text { seasons }\end{array}$ & $\begin{array}{l}\text { Samoan } \\
\text { seasons }\end{array}$ \\
\hline February & Toeutuva & Digging yams again & Summer & $\begin{array}{l}\text { Vai To'elau - the 'north } \\
\text { easterly winds' season }\end{array}$ \\
\hline March & $\begin{array}{l}\text { Fa'aafu } \\
\text { Ta'afanua } \\
\text { Aitu iti }\end{array}$ & $\begin{array}{l}\text { Withering of the yams } \\
\text { Walk or Roam the land } \\
\text { Small Gods }\end{array}$ & & \\
\hline April & $\begin{array}{l}\text { Lo } \\
\text { Fanoga }\end{array}$ & $\begin{array}{l}\text { Small fish } \\
\text { Destruction. }\end{array}$ & Autumn & \\
\hline May & $\begin{array}{l}\text { Au nunu } \\
\text { Sina }\end{array}$ & $\begin{array}{l}\text { Stem crushed. } \\
\text { Goddess white }\end{array}$ & & \\
\hline June & Ologa manu & The singing of birds & & \\
\hline July & Palolo mua & The first palolo-virides & Winter & $\begin{array}{l}\text { Vai Palolo-the } \\
\text { 'virides' season }\end{array}$ \\
\hline August & Palolo muli & The last palolo & & \\
\hline September & Muli fa & $\begin{array}{l}\text { End of the stem of a taro- } \\
\text { colo cassia esculenta }\end{array}$ & & \\
\hline October & Lotu O Uaga & Rain players & & \\
\hline November & Taumafa mua & The first of plenty & Spring & \\
\hline December & $\begin{array}{l}\text { Taumafa muli } \\
\text { Toe Taumafa }\end{array}$ & $\begin{array}{l}\text { The final meal/feasting } \\
\text { The final supper }\end{array}$ & & \\
\hline January & Utuvamua & Digging of the first yams & & \\
\hline
\end{tabular}




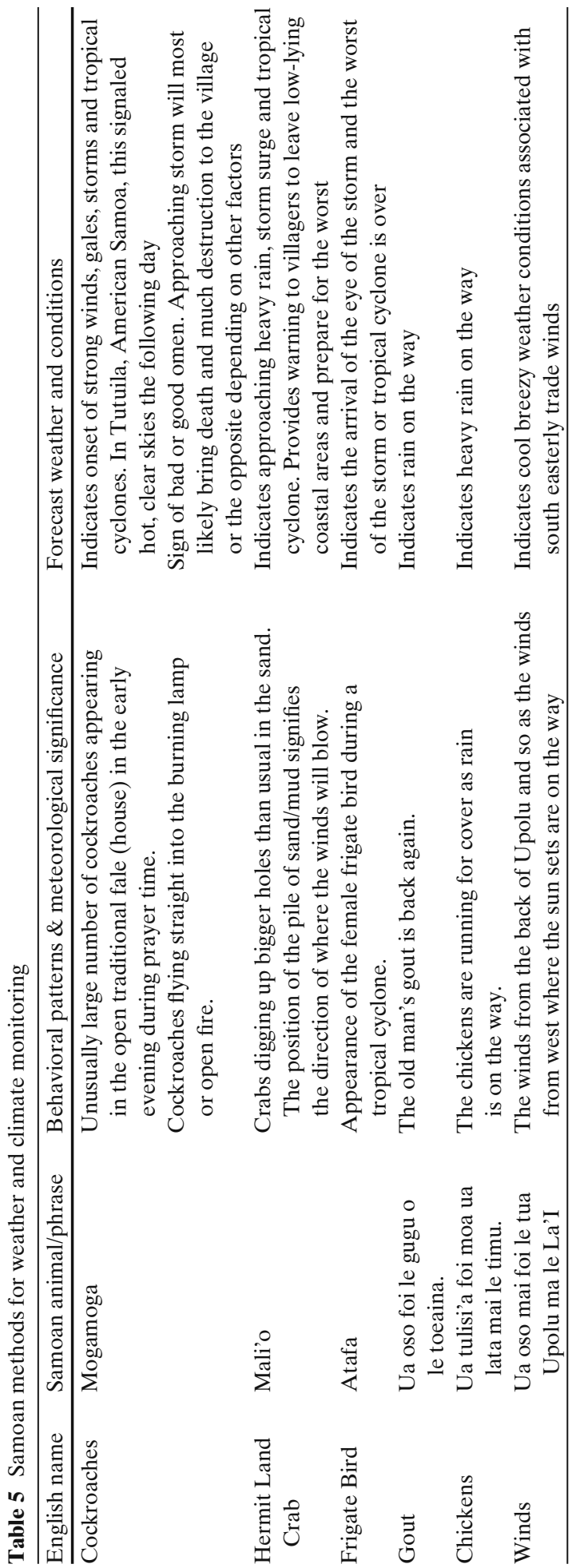


The two main seasons are; the Vaipalolo season which begins at Toepalolo (August) and extends to Utuvamua (January) and Vaitoelau, which begins with Toeutuva (February) and extends to Palolomua (July) (Brown et al. 1974).

From all accounts the palolo has a major influence in the formulation of the Samoan seasonal calendar, as described by Brown (Brown et al. 1974);

It is very surprising the signs (portents) which are connected with Palolo. Their coming is accompanied with (or causes) hurricanes, rains, many troublesome contrary winds, and heavy breakers. Their influence continues until they have entered into hiding. Then there is quiet. The calm only comes when the palolo has escaped into hiding again. Behold the little fish how surprising it is that it should have such influence as to cause the heavens to shake with thunder and also the lightning. It is just like a chief.

Based on the 'chiefly' status of the palolo in the Samoan seasonal calendar, it is highly likely that the key environmental change that distinguishes the seasons in Samoa is mark by appearance and disappearance of the palolo. The rise and fall of the palolo is greatly influence by weather and climate and occurrence of extreme climate events.

\subsection{Samoan methods of climate and weather observations}

The literature review and interviews revealed a variety of methods used by the Samoans to observe weather and climate (Table 5). Although some are well known, many of the details are remain to be resolved. The cockroach methodology, for example, is acceptable to some villages in Samoa while others do not subscribe to it. In other cases, conflicting interpretation of the same method and observation varies from village to village. Many of the mythologies extensively documented by missionaries, suffers a similar fate (Brown et al. 1974; Turner 1884). Different villages have different versions of these methods depending on factors such as geographic location, beliefs, genealogies, their origins and traditions.

\subsubsection{Comparison}

Table 6 provides a summary of a possible explanation of the relationship between the Samoan and scientific methods of climate observations.

Table 6 Samoan methods of climate and weather observations and possible western scientific equivalent

\begin{tabular}{|c|c|c|}
\hline Samoan indicator/phrase & English & $\begin{array}{l}\text { Possible scientific } \\
\text { tool equivalent }\end{array}$ \\
\hline Mogamoga & Cockroaches & Barometer \\
\hline O le malio/kupa ma lona lua & The Hermit Crabs and its hole & Anemometer \\
\hline O le Atafa & Frigate Bird & Anemometer \\
\hline $\begin{array}{l}\text { Ua oso foi le gugu o le toeaina } \\
\text { o le a sau le timu }\end{array}$ & $\begin{array}{l}\text { The old man's gout is back, } \\
\text { rain is on the way }\end{array}$ & Barometer \\
\hline $\begin{array}{l}\text { Tulisi'a foi moa ua } \\
\text { lata mai le timu }\end{array}$ & $\begin{array}{l}\text { Chickens are running scared the } \\
\text { rain is on its way }\end{array}$ & $\begin{array}{l}\text { Anemometer } \\
\text { Solarimeter } \\
\text { Thermometer }\end{array}$ \\
\hline
\end{tabular}




\section{Discussion}

\subsection{Theoretical implications of this research}

The main goal of this research is to document and evaluate the potential role of traditional ecological knowledge in weather and climate and how this could be integrated into contemporary western scientific methodologies of weather and climate observations, research and assessment and response to human induced climate change. Placing our findings back into the wider context of not only western scientific meteorological theory but also wider human science theory raises two issues worthy of comments.

First, it is clear from this research that future work on traditional ecological knowledge cannot blindly assume homogeneity in the knowledge structures held within both indigenous and western scientific communities.

Second, if it is accepted that traditional ecological knowledge of weather and climate like those practiced by the Samoans are accepted as having a role in further understanding western scientific knowledge of climate change, the key challenge for researchers is to work out how this process could be carried out and mediated in order to integrate the two vastly different approaches and concepts.

The first theoretical implication of this work relates to the highly contested issue of the type of research method to be used to document and share traditional ecological knowledge systems. Much has been written about this topic. One of the major weaknesses of this research is not engaging a social scientist, who speaks the local language and understand local customs and processes to be part of the research. It is recommended that further research in this area be carried out by a joint team of pure scientists and social scientists. It is worth noting though that this research has greatly improved climate scientists understanding of the complex issues involving human and social sciences. In order to be able to extract traditional ecological knowledge from reliable sources, it is crucial that the researcher be flexible, patient and embrace the different nature and types of processes involved, such as the sometimes casual and informal manner (talanoaga faasamasamanoa) in which the information is presented, but above all the need to earn the trust of local communities is paramount.

The research revealed Samoans appear to have limited knowledge and understanding of broader and region wide meteorological features driving the weather and climate of the whole Pacific region. Despite an extensive search for information on any references or linkages between Samoan traditional ecological knowledge of weather and climate and key meteorological features of the region like the ENSO, El Niño, La Niña, SPCZ, ITCZ and IPO, it was not possible to find any.

But one area that appears to stand out in terms of the linkages between Samoa traditional ecological knowledge and western scientific knowledge of climate and weather is the methods used to monitor and observe weather and climate. Table 5, for example, provides a comparison of the Samoan methods of weather and climate observations and those of western scientific techniques. It appears there is a close correlation. It also appears biological science plays a key role in the manner in which Samoans tend to select environmental changes in nature to monitor and observe local changes in climate and weather. This suggests the importance of analyzing the linkages between the biological make up of some of the animals and plants used by the Samoans to detect changes in meteorological parameters. 


\subsection{Practical implications of this research}

Since this research is the first in the Pacific Islands to explore this area, it has provided a good start to guide future research in this field. The research has established a foundation for formulating research questions and hypothesis in the traditional ecological knowledge of weather and climate research field. It has acted as a first source of traditional ecological knowledge of climate and weather history and baseline data. It has provided insights into how indigenous communities like the Samoans could anticipate, plan, respond and adapt to the likely impacts of human induced climate change and long-term community based weather and climate monitoring. The findings from this research are consistent with those found in other similar studies elsewhere (Riedlinger and Berkes 2000; Berkes 2001; Yohe et al. 2007).

\section{Conclusions}

The findings from this research confirm there is definitely a major role for traditional ecological knowledge of weather and climate to play in advancing our western understanding of climate and weather. In view of the accurate naming and predicting of changes in weather and climate by the Samoans, similar research should be carried out in other indigenous Pacific Island communities to further advance our understanding of changes in weather, climate and climate change throughout the region. This research has identified some of this knowledge in Samoa. However, there is a good chance there is still more unknown and only careful long-term studies will begin to reveal this wealth of knowledge.

This research demonstrates that traditional ecological knowledge of weather and climate is just as important as western scientific knowledge in planning for future climate change. The ability and knowledge of indigenous communities, as demonstrated by the Samoans, to accurately predict the onset of extreme climate events, relying solely on local knowledge and environmental changes, should be further investigated as part of the human dimensions of climate change research. However, Samoans appear not to have a broader knowledge of key meteorological features like the ENSO, SPCZ, IPO, ITCZ, driving climate and weather of the tropical western Pacific region. Their knowledge is highly likely to be predominantly rooted in local environmental changes and conditions.

Acknowledgements I have received many helpful comments from various people during the course of this research. I would like to acknowledge the following individuals; Professor Richard Moyle, Anthropology Department, University of Auckland, Dr Jon Barnett, Anthropology and Human Science Department, University of Melbourne, Australia, who provided advice in the areas of human science research and methodology. I also would like to acknowledge the wonderful support from my NIWA colleagues, Dr Jim Salinger, Dr David Wratt, Dr Guy Penny, Georgina Griffiths and Darren King. Finally, many thanks to staff of the Samoa Meteorological Service, Apia Observatory, Mulinuu, Apia, Samoa, and US NOAA Weather Office in Pagopago, American Samoa, for their wisdom and advice on this research, in particular, Chief Ta'ala Pauga, Ta'ala Liae, Mulipola Ausetalia Titimaea, and Faatoia Malele (Apia Observatory) and Chief Utu Abe Malae, Chief Leilua Akapo Akapo (Senior Meteorologist), NOAA Weather Office, American Samoa. My deep thanks to Matiu Ligaliga Fatu Lefale of Utualii, my father, whom when I was a loner but very inquisitive, curious six years old about the world we live in, I asked him the following questions "Where do tropical cyclones originate from? What can be done to minimise their impacts?" His response was "You go and find 
out yourself". This paper is very much a part of my long arduous but exciting journey to addressing my father's challenge. This research was supported by the New Zealand Foundation for Research, Science and Technology (FRST) under contract No. CO1X0202-Adaptation to Climate variability and change.

Open Access This article is distributed under the terms of the Creative Commons Attribution Noncommercial License which permits any noncommercial use, distribution, and reproduction in any medium, provided the original author(s) and source are credited.

\section{References}

Barnett J, Busse M (2002) Ethnographic perspectives on resilience to climate variability in Pacific Island countries. In: Asia-Pacific Network (APN) Secretariat (ed) APN, Asia-Pacific network for global change research, projects 2001/2002. Kobe, Japan, pp 45-48

Berkes F (1993) Traditional ecological knowledge in perspective. In: Inglis JT (ed) Traditional ecological knowledge: concepts and cases. International Program on Traditional Ecological Knowledge and International Development Research Centre, Canada, p 3

Berkes F (2001) Making sense of artic environmental change? In: Krupnik I, Jolly D (eds) Navigating social-ecological systems, building resilience for complexity and change. Cambridge University Press, Cambridge, pp 335-349

Beucher F (1997) Large scale circulation dynamics in the South-West Pacific, vol 1. National Institute of Water and Atmospheric Research (NIWA), Aukland, pp 178-195

Brown G, Penisimani 1861-1870 (1974) Rev George Brown Papers, Penisimani, Samoan stories, vols 1 and 2, part A, pp 1-132, part B, pp 1-79. Council of the Library of New South Wales, manuscript in the Mitchell Library, CY Reel 181, filmed by W. \& F. Pascoe Pty. Ltd., NSW, Australia, pp 1-11

Burgess S (1988) The climate and weather of Western Samoa. New Zealand Meteorological Service, Wellington

Correa CM (2001) Traditional knowledge and intellectual property: issues and options surrounding the protection of traditional knowledge; A discussion paper. Quaker United Nations Office Geneva (QUNO), Geneva. http://www.quno.org.org

Cram F (1996) Developing partnerships in research: Pakeha researchers and Maori research. Master thesis, University of Auckland, Auckland, New Zealand, pp 2-9

Cristensen JH, Hewitson B, Chen A, Gao X, Held I, Jones R, Kolli RK, Kwon WT, Laprise R, Magana Rueda V, Mearns L, Menendez CG, Raisanen J, Sarr A, Whetton P (2007) Regional climate projections. In: Solomon S, Qin D, Manning M, Chen Z, Marquis M, Averyt KB, Tignor M, Miller HL (eds) Climate change 2007: the physical science basis. Contribution of working group I to the fourth assessment report of the intergovernmental panel on climate change. Cambridge University Press, Cambridge

Davis S (1997) Documenting Aboriginal seasonal calendar. In: Webb E (ed) Windows on meteorology: Australian perspective. CSIRO Publishing, Collingwood, VIC

Folland CK, Renwick JA, Salinger MJ, Mullan B (2002) Relative influences of the Interdecadal Pacific Oscillation and ENSO on the South Pacific Convergence Zone. Geophys Res Lett 29(13):1643

Generic Resources Action International (GRAIN) (2003) Model law for the protection of traditional ecological knowledge, innovations and practices. http://www.grain.org/docs/brl-modellaw-pacific-ene.pdf

Generic Resources Action International (GRAIN) and Kalparvriksh (2002) Traditional knowledge of biodiversity in Asia-Pacific: problems of piracy and protection. New Delhi, India. http://www.grain.org/publications/tk-asia-2002-en.crfm

Hastenrath S (2002) The intertropical convergence zone of the Eastern Pacific revisited. Int J Climatol 22:347-356

Jolly D, Berkes F, Castleden J, Nichols and the Community of Sachs Harbour (2002) We can't predict the weather like we used to: inuvialuit observations of climate change, Sachs Harbour, Western Canadian Artic. In: Krupnik I, Jolly D (eds) The earth is faster now, indigenous observations of arctic environmental change. Arctic Studies Centre, Washington, pp 93-125 
Kerr IS (1976) Tropical storms and hurricanes in the Southwest Pacific, November 1939 to April 1969. New Zealand Meteorological Service, NZ Met. S. Misc. Pub. 148, Wellington, New Zealand, pp 86-88

Lefale P (2006) Climate trends and projections for small islands of the Tropical South West Pacific. In: Chapman R, Boston J, Schwass M (eds) Confronting climate change: critical issues for New Zealand. Victoria University Press with Institute of Policy Studies, Wellington, pp 95-101

Manton MJ, Della-Marta PM, Haylock MR, Hennessy KJ, Nicholls N, Chambers LE, Collins DA, Daw G, Finet A, Gunawan D, Inape K, Isope H, Kestin TS, Lefale P, Leyu CH, Lwin T, Maitrepierre L, Ouprasitwong N, Page CM, Pahalad J, Plummer N, Salinger MJ, Suppiah R, Tran VL, Trewin B, Tibig I, Yee D (2001) Trends in extreme daily rainfall and temperature in Southeast Asia and the South Pacific: 1961-1998. Int Climatol 21:269-284

McCarthy JJ, Canzianni FO, Leary AN, Dokken DJ, White KS (eds) (2001) Climate change 2001: impacts, adaptation, and vulnerability. Contribution of working group II to the third assessment report of the intergovernmental panel on climate change. Cambridge University Press, Cambridge, pp 843-876

Meleisea M (1987) Lagaga, a short history of Western Samoa. University of the South Pacific, Oceania Printer, Suva, Fiji

Mimura N, Nurse L, Mc Lean RF, Agard J, Briguglino L, Lefale P, Payet R, Sem G (2007) Small islands. In: Barry ML, Canziani OF, Palutiko JP, van der Linden PJ, Hanson CE (eds) Climate change 2007: impacts, adaptation and vulnerability. Contribution of working group II to the fourth assessment report of the intergovernmental panel on climate change. Cambridge University Press, Cambridge, pp 687-716

Overton J (1999) Sustainable development and the Pacific Islands. In: Overton J et al (eds) Strategies for sustainable development, experiences from the pacific. Zed, London, p 3

Pratt G (1862) Pratt's grammar \& dictionary of the Samoan language. Malua Printing Press, Malua (reprinted 1960)

Riedlinger D, Berkes F (2000) Contributions of traditional knowledge to understanding climate change in the Canadian Arctic. http://www.arcus.org/award/pdf/5th_pdf/Riedlinger Abstract.pdf

Saifaleupolu S (1985) The Influence of the Southern Oscillation on the climate of Western Samoa. Masters thesis, Victoria University of Wellington, Wellington, New Zealand

Salinger MJ (2001a) Climate shifts in the South Pacific. In: Wolfgang S (ed) Proceedings science component, linking science and policy, Pacific Islands conference on climate change, climate variability and sea level rise. National Tidal Facility, The Finders University of South Australia, Adelaide, pp 67-72

Salinger MJ (2001b) Climate variation in New Zealand and the Southwest Pacific. In: Sturman A, Spronken-Smith R (eds) The physical environment. A New Zealand perspective. Oxford University Press, Victoria

Salinger MJ, Jones PD (1996) Southern hemisphere climate: the modern record. In: Banks MR, Brown MJ (eds) Climatic succession and glacial history of the Southern Hemisphere over the last five million years. Pap Proc R Soc Tasman 130(2):101-107

Salinger MJ, Renwick JA, Mullan AB (2001) Interdecadal Pacific Oscillation and South Pacific climate. Int J Climatol 21:1705-1721

Shea E, Dolcemascolo G, Anderson CL, Banston A, Guard CP, Hamnett MP, Kubota ST, Lewis N, Loschinigg J, Meehls G (2001) Preparing for a changing climate. The potential consequences of climate variability and change, Pacific Islands. A report of the Pacific Islands regional assessment group for the U.S. Global Change Research Program. East West Centre, University of Hawaii, Honolulu, Hawaii

Terralingua (2003) Definition: traditional Ecological Knowledge (TEK). Partnership for linguistic and biological diversity, USA. http://www.terralingua.org/Definitions/DTek.html

The Cyclopedia of Samoa, Tonga, Tahiti, and the Cook Islands (Illustrated) (1907) A complete review of the history and traditions and the commercial development of the islands, with statistics and data never before compiled in a single publication. Sydney, NSW, pp 11-48

Trenberth KE (1976) Spatial and temporal variations of the Southern Oscillation. Q J R Meteorol Soc 102:639-653

Turner G (1861) Nineteen years in Polynesia: missionary life, travels, and researches in the islands of the Pacific. John Snow, Paternoster Row, London, pp 245-255

Turner G (1884) Samoa: a hundred years ago and long before. London Missionary Society, first printed London 1884, reprinted 1984, 1986, 1989, Institute of Pacific Studies, University of the South Pacific, Suva, Fiji, pp 3-9, 201 
World Intellectual Property Organization (WIPO) (1999) Experts discuss traditional knowledge and the intellectual property system. WIPO press release PR/99/195, Geneva, 2 November 1999. In www.wipo.org/pressroom/en/releases/1999/p195.htm

Yohe GW, Lasco RD, Ahmad QK, Arnell NW, Cohen SJ, Hope C, Janestos AC, Perez RT (2007) Perspectives on climate change. In: Barry ML, Canziani OF, Palutiko JP, van der Linden PJ, Hanson CE (eds) Climate change 2007: impacts, adaptation and vulnerability. Contribution of working group II to the fourth assessment report climate change 2007. Cambridge University Press, Cambridge, pp 832-834 